\title{
Gender Differentials in Tuberculosis: Impact of Socio-Economic and Cultural Factors Among the Tribals of Northeast India
}

\author{
Mary Grace Tungdim ${ }^{*}, 1$ and Satwanti Kapoor ${ }^{*}, 2$ \\ Department of Anthropology, University of Delhi, Delhi-110007, India
}

\begin{abstract}
The cross-sectional sample included 167 adult males and 153 adult females in the age group (20-40) yrs who were diagnosed and confirmed cases of tuberculosis. The data was collected from August 2000 to July 2001 from different TB centers in Manipur, Northeast India. The socio-economic and cultural factors were assessed from the living conditions, literacy status, annual per capita income, occupation, marital status, age at marriage and BCG vaccination status. Female patients were found to have significantly lower level of socio-economic status as judged from education level, occupations or living condition as compared to their male counterparts. Female patients were also found to marry at a very young age and they were also found to take their TB medicines regularly than their counterpart males.
\end{abstract}

Keywords: Gender, Tuberculosis, Northeast India, Socio-economic Status, Tribals.

\section{INTRODUCTION}

Tuberculosis is an ancient disease. It is one of the major public health problems in the world today and no other disease has so much sociological, economic and health significance as tuberculosis. There is no country free from tuberculosis though quite a few have eliminated the disease as a public health hazard. Morbidity and mortality from tuberculosis are concentrated mostly in the poor third world countries. Inspite of the increase in the rate of notification, TB still remains a low priority in many developing countries. An estimated millions of new cases occur each year, resulting in 2-3 millions death, despite the widespread availability of highly effective treatment regimens $[1,2]$. Majority of the TB cases are found in the developing countries and in the economically productive age group i.e.15-50 yrs [3]. In India tuberculosis continues to be a major public health problem and about 2 million cases occur every year, every minute one person dies due to tuberculosis and two persons become sputum positive [4].

There is clear evidence that there is a close link between TB and poverty that highlights the relevance of gender issues in the context of prevalence and treatment of TB in developing countries [5]. Women are faced with heavier burden of poverty that make them more vulnerable to adverse social and environmental conditions. The few studies on gender differences in TB done from the Third World countries suggest differences in diagnosis, treatment and societal perceptions of TB in women usually to their disadvantage and reflecting their lower social status in many societies [6-8].

Tuberculosis is the greatest single infectious cause of death in women worldwide. The consequences of tuberculosis in women are far reaching affecting women them-

*Address correspondence to this author at the Department of Anthropology, University of Delhi, Delhi-110007, India; 'Tel: 011-27601795, 01127667329; E-mail: marygracezou@yahoo.co.in; ${ }^{2}$ Tel: 011-27667297, 01127667329; E-mail: satwanti@yahoo.com selves, their children and the society in general. TB in women creates orphans, impoverishes families and reduces the economic development of a society. Besides the disease burden, TB also causes an enormous socio-economic burden. Tuberculosis is a disease commonly associated with poverty, overcrowding, and malnutrition. Socio-economic status, whether measured by education, income or other indices of social class, has long been known to be associated with mortality from different disease [9-12].

The present paper attempts to understand the gender differentials amongst tuberculosis patients on their socioeconomic and cultural aspect.

\section{MATERIALS AND METHODOLOGY}

The present study was conducted among adult tribal males and females in Manipur. Manipur lies in the NorthEastern region of the Indian sub-continent, between $23^{\circ} 50^{\prime}$ latitudes and $25^{\circ} 30^{\prime}$ North and $93^{\circ} 10^{\prime}$ and $94^{\circ} 30^{\prime}$ East longitudes, bordering Myanmar in the East, Nagaland in the North, Assam and Mizoram in the West. The density of population is 82 per sq.km., the literacy rate is $59.89 \%$ and the per capita income is Rs. 3502/- [13].

According to the 1991 census report, Manipur has a population of around $1,837,149$ out of which the tribal population accounts for approximately 30 percent. In the geographical classification it may be simply divided into a valley at the center and the hills surrounding it. The hills are said to be abode of the tribals. It should be noted that all the different ethnic groups are of the same Mongoloid group and have very close similarities in their culture and traditional habits. The main occupation of the people is agriculture and rice is their staple food.

The sample was collected from the different tribes of Manipur viz:: Tangkhuls, Hmars, Kabuis, Kukis, Paites and Zous. 

are:

The ethnographic profiles of the various tribes studied

\section{Tangkhuls}

The chieftainship is an age-old institution among the Tangkhuls. The chief is called 'Awunga' in Tangkhul dialect, which is equivalent to English word 'King'. The Tangkhuls were one of the most powerful tribes of the hills as far as the Chindwin. They occupy the Eastern hills of Manipur. In every village there is a hereditary chief. In rare cases, there are two or more chiefs in a village. Hungyo [14] in his study found that in Bungpa, "there are two chiefs representing the two clans of the village. In exceptional cases, the leaders of the clan groups, during their migration period, agreed to settle down in a particular place without submitting the leadership. In such cases, the leaders of the respective groups maintained their identity and hence we find two or more chiefs in a village. There are many big villages with several clans, which have one chief each. Therefore, the number and size of the clans in a village are not the criteria for having two or more chiefs in a village".

The Tangkhuls strictly follow patriarchal and patrilineal system and therefore, the chieftainship passes on from father to the son. If the chief has no male child, the nearest kin succeeds him. Under normal circumstances, it can never be transferred to any other person. In case the chief dies without a male child and the next man who would succeed him is mentally retarded then a person from the same clan may perform the burial ceremony of chief in a befitting manner and may become the chief. He must be a man of dignified character who is acceptable by the villagers.

\section{Hmars}

The Hmars belongs to the Chin-Kuki-Mizo group. Their origin is traced back to ' $k h u l$ ' in Central China. The Hmars are mainly found in the South of Manipur [15]. The main source of livelihood of Hmars is agriculture. Hmars practice settled cultivation and forest constituted the main source of several products particularly timber, teak, pines, sal, oak, bamboo, etc. According to Lal Dena [16] "internally the economic activity of Hmars was marked by the absence of market oriented production. The process of distribution took the form of gift and counter gift and ceremonial exchange and the distribution involved channeling upward of products and services to socially determined allocative centers such as chiefs, priest and blacksmiths". The Hmars are hard working people and have trade relation with Cacharis, Bengalis, etc. and the main items of exchange were cotton, chilly and later on orange and pineapple, which were exported in large quantities mainly through the Barak river.

According to Lal Dena [16], "as the Hmar society became more stable with settled agriculture as the mode of production, the position of chiefs became more and more deep-rooted in the society. Each Hmar village possessed a definite area of territory". It is assumed that at some stage, the communal ownership of land was the basic feature of the land tenure system among the Hmars and that it is the common property of the people and the chief and the councillors are trustees with the power to see the rightful use and distribution of land to each household for cultivation. The actual practice, however, presented a contrasting picture. The chief of the Hmar village called 'Lal' was a 'Maharaja' of a petty state [17]. The chief is in fact, the sole owner of the land and his rights can almost be compared with that of a Zamindar in other parts of the country. The villagers were something like tenants-at-will who paid 'Busung-Sadar' and rendered forced labour to the chiefs. The 'Busung-Sadar' is the practice of paying every year of certain specified quantity of rice (Busung) and of surrounding the forelegs of every animal (Sadar) shot or trapped within the chiefdom as rent and 'rendered forced labour' which involved building or rebuilding the chief's house and any other services whenever asked for without any wage [16].

\section{Kabuis}

The Kabuis occupy the hills between Cachar and the valley of Manipur in the West. There are however, quite a number of Kabui villages in the valley. By and large, the Kabuis in the valley are more advanced than those living in the hills. Among the Kabuis of the plains many are found in white collared jobs. The tribe can be said to belong to two different groups namely, the Hill Kabuis and the Plain Kabuis. The Kabuis are divided into at least four exogamous clans. They are Kamei, Golmei, Gangmei and Longmei. It is customary for a Kabui to seek his spouse outside his own clan. Intra-clan marriage is prohibited [18].

The chief is called 'Khullakpa' in Kabui dialect. The 'Khullakpa' is the head of the village administration. The village administration consists of council of members headed by the 'Khullakpa' and the other members are 'Khunbu, Luplakpa and $M u$ (Medicine man)'. The chief is hereditary while the others are not. Divorce is permitted on account of barrenness or incompatible temperament between the spouses. Though many of the Kabuis have converted into Christianity, still many, retain their traditional beliefs and the worshipping place for them is called 'Haipei pui laa kai'. The Kabuis have different organization for the boys, girls and the aged persons. These are the so-called dormitories, which are the centers for various social and cultural trainings. The girls' dormitory is locally known as ' $L u c h u$ '. All the girls have to be a member of this organization before their marriage. The boys' dormitory is locally known as 'Khangchu'. All the boys of marriageable age are members of this organization and retain their membership till their marriage. At the time of wedding feast or the community feast, members of the boys' dormitory cook and look after the guests. The organization for the aged persons is locally known as 'Kengjapui' [18].

\section{Kukis}

The old Kukis are democratic communities, while the new Kukis are subjects to the chiefs. Among the Thadous there were different types of chiefs, some had royal lineage [19]. Stewart [20], had categorically stated that "the Kookis are naturally a migratory race, never occupying the same place for more than two, at the utmost three years". Shaw [21], also observed similar situation among the Thadous, "persons who are not related to Thadou chiefs are to be seen as heads of the villages just because they have some wealth 
behind and are, in consequence, able to get some ready followers". Hutton [22], observed that "Thadoes, ruled as they are by their own well recognized elders and managed their own affairs in their own way and had recourse to the courts only in exceptional cases". The Kukis were warlike people and hence they were engaged by the Maharaja of Manipur to safeguard the land bordering Myanmar in the East. It was during this time that they settled side by side with the Tangkhul Nagas. The Kukis are also concentrated in South and Tengnoupal districts. The chief is called 'Hausapu' in Kuki dialect. In every village there is a hereditary chief.

\section{Paites}

Paites belong to the Chin-Kuki-Mizo group. They are concentrated mostly in Churachandpur district. Unlike the other Chin-Kuki-Mizo tribes, the Paites organize themselves very well and excel in many fields. They are considered to be one of the most advanced tribe in India. The Paites were one of the first tribe to get converted into Christianity, which is the main reason for their advancement. The Paites amend their customs and traditions to suit the modern society. The village administration is in the hands of the village chief and the chieftainship is hereditary. The chief is locally called 'Hausa'.

\section{Zous}

The Zous are believed to have originated from 'Khul' (cave) in Central China and it was during this time that Zou (Zhou) dynasty ruled China from $1027 \mathrm{BC}$ to $256 \mathrm{BC}$ [23]. They are the descendents of the three brothers namely: Songthu, Songza and Zahong. Zous are the eldest of the Chin-Kuki-Mizo tribe. The Zous belong to the Mongoloid stock allied to the Tibeto-Burmans and whose stories dates back to $2000 \mathrm{BC}$ [24].

The Zous have their own customs and customary laws. Any Zou who is found guilty of a crime will be tried under

Table 1. Distribution of Subjects According to Living Conditions among Males and Females

\begin{tabular}{|c|c|c|c|c|}
\hline \multicolumn{2}{|c|}{ Living Conditions } & \multirow{2}{*}{$\begin{array}{c}\begin{array}{c}\text { Males (\%) } \\
(\mathbf{N}=\mathbf{1 6 7})\end{array} \\
60.48\end{array}$} & \multirow{2}{*}{$\begin{array}{c}\begin{array}{c}\text { Females }(\%) \\
(\mathbf{N}=\mathbf{1 5 3})\end{array} \\
63.40\end{array}$} & $\chi^{2}$ \\
\hline \multirow{2}{*}{ Electricity } & Yes & & & \multirow{2}{*}{0.29} \\
\hline & No & 39.52 & 36.60 & \\
\hline \multirow{5}{*}{ Source of bathing/washing water } & Piped (PHED water supply) & 8.38 & 7.84 & \multirow{5}{*}{5.75} \\
\hline & Hand pump & 31.14 & 34.64 & \\
\hline & Well water & 13.77 & 9.15 & \\
\hline & Pond water & 21.56 & 18.95 & \\
\hline & Others & 25.15 & 29.42 & \\
\hline \multirow{4}{*}{ Source of drinking water } & Piped (PHED water supply) & 46.71 & 15.03 & \multirow{4}{*}{$41.69 * *$} \\
\hline & Hand pump & 8.38 & 18.95 & \\
\hline & Well water & 20.96 & 39.87 & \\
\hline & Others & 23.95 & 26.15 & \\
\hline \multirow{3}{*}{ Sanitation facility } & Proper toilets & 11.98 & 19.61 & \multirow{3}{*}{4.95} \\
\hline & Non-septic toilets/latrines & 76.04 & 73.20 & \\
\hline & Open fields & 11.98 & 7.19 & \\
\hline \multirow{5}{*}{ Type of fuel for cooking } & Wood & 44.31 & 37.91 & \multirow{5}{*}{4.95} \\
\hline & Charcoal & 41.32 & 40.52 & \\
\hline & Kerosene & 1.20 & 1.31 & \\
\hline & Electricity & 2.39 & 1.31 & \\
\hline & Liquid petroleum gas & 10.78 & 18.95 & \\
\hline \multirow{3}{*}{ Type of house } & Kachcha & 50.30 & 53.59 & \multirow{3}{*}{4.47} \\
\hline & Semi-pucca & 45.51 & 37.26 & \\
\hline & Pucca & 4.19 & 9.15 & \\
\hline \multirow{3}{*}{ Place where livestock were kept } & Inside the house & 18.56 & 18.95 & \multirow{3}{*}{0.06} \\
\hline & Outside the house & 31.74 & 32.68 & \\
\hline & No livestock & 49.7 & 48.37 & \\
\hline \multirow{4}{*}{ Persons per room } & $<3$ & 16.18 & 13.07 & \multirow{4}{*}{2.19} \\
\hline & $3-5$ & 44.31 & 41.18 & \\
\hline & $6-7$ & 32.33 & 34.64 & \\
\hline & $8+$ & 7.18 & 11.11 & \\
\hline
\end{tabular}

PHED-Public Health Engineering Department

$* * \mathrm{p}<0.01$ 
the Zou custom. The United Zomi Organization (UZO) is a political body of the Zous and was formed in the year 1967. The Zous had their own script but due to the course of migration lost them. The lost script is now depicted by $\mathrm{Mr}$. Siahzathang of Lamka, Churachandpur. The Zous are the only tribe who have their own script in the whole of Northeast India. The chieftainship among the Zous is hereditary. The chief is locally known as 'Hausa'. Zous are mainly found in the South and Chandel districts of Manipur while many of them are found in Myanmar. Mr. Grierson comments, "The Zous are said to be slow in speech, serious in manner, respect for births and pride of pedigree, the duty of revenge, love of drink, virtue of hospitality, clan prejudices, avarice, distrust, impatience of control and dirt".

A cross sectional study among the adult pulmonary tuberculosis (TB) patients between 20-40 years of age was conducted in the four TB centers in Manipur. The TB patients were selected on voluntary basis. A total of 320 adult males and females who were diagnosed as suffering from tuberculosis were included in the present study. The sample was collected from Aug 2000 to July 2001. The TB patients were confirmed case of pulmonary TB and who were under DOTS treatment as confirmed from the doctors in the TB center. The age of the subjects were cross-checked from the date of birth, age of the eldest child and age at marriage, etc. None of the subjects were related to each other by birth or by marriage. The TB subjects came to various TB centers/hospital for constant monitoring. It is worth mentioning here that the males and females were independent of each other.

The guidelines for selection were laid down and all volunteers fitting into that guideline frame were accepted as part of the study. A well-informed written consent from the subjects for their willingness to participate in the present study was taken before the interviews were taken.

All data was analyzed using SPSS 13.0 version.

\section{RESULTS}

The details of the living conditions are presented in Table 1. Among males, $60.48 \%$ had electricity connection whereas among females $63.40 \%$ had electricity connection. Maximum males (31.14\%) used hand pumps as the source of bathing or washing water followed by $25.15 \%$ who used other sources like rain water, spring water, etc. $21.56 \%$ used pond water and only $8.38 \%$ males used piped water supply of Public Health Engineering Department (PHED). Among females maximum used hand pumps (34.64\%) followed by water from other sources $(29.42 \%)$ and only $7.84 \%$ used piped water supply from PHED. The main source of drinking water among males $(46.71 \%$ ) was from piped water supply of PHED and among females (39.87\%) it was well water. With regard to sanitation facilities very few males and females had proper toilets. Around $76.04 \%$ males and $73.20 \%$ females used non-septic toilets. The type of fuel used for cooking was wood for $44.31 \%$ males as compared to $37.91 \%$ among females followed by charcoal users among $41.32 \%$ males and $40.52 \%$ females. About $50 \%$ of males and females lived in kachcha houses followed by pucca and few lived in pucca houses. Majority of the subjects keep their livestock outside their houses. Among males $44.31 \%$ had 3-5 persons living per room followed by 6-7 persons per room $(32.33 \%)$. And in females $41.18 \%$ had 3-5 persons living per room followed by 6-7 persons living per room (34.64\%).

Table 2 presents the percentage distribution of subjects according to literacy status. The highest number of males were in the primary level of education $(56.29 \%)$ followed by secondary level (23.35\%) and then graduation $(10.78 \%)$ and $9.58 \%$ were illiterates. Among females the highest percentage were among primary level education $(60.13 \%)$ followed by illiterates $(21.57 \%)$ and secondary level education (14.37\%). Among females only $3.92 \%$ were graduates.

Table 2. Distribution of Subjects According to Literacy Status among Males and Females

\begin{tabular}{|c|c|c|c|}
\hline Literacy Status & $\begin{array}{c}\text { Males(\%) } \\
(\mathrm{N}=167)\end{array}$ & $\begin{array}{c}\text { Females(\%) } \\
(\mathrm{N}=153)\end{array}$ & $\chi^{2}$ \\
\hline Illiterate & 9.58 & 21.57 & \multirow{4}{*}{$16.07^{* *}$} \\
\hline Primary & 56.29 & 60.13 & \\
\hline Secondary & 23.35 & 14.37 & \\
\hline Graduation & 10.78 & 3.93 & \\
\hline
\end{tabular}

Table 3 presents the percentage distribution of subjects according to the annual per capita income. Among males, maximum (43.72\%) had annual per capita income (APCI) less than or equal to Rs. $3000 /-(75$ US\$) followed by $27.54 \%$ whose APCI was between Rs. 3001/- to Rs. 6000(75.025150 US\$), $14.37 \%$ whose APCI between Rs. 6001 to Rs.9000 (150.025-225 US\$), 8.38\% had APCI between Rs. 9001 to Rs. $12000 /-(225.025-300$ US\$-) and $5.99 \%$ with APCI above Rs. 12000(>300 US\$).

Table 3. Distribution of Subjects by Annual Per Capita Income among Males and Females

\begin{tabular}{|c|c|c|c|}
\hline $\begin{array}{l}\text { Annual per Capita Income } \\
\text { (APCI) }\end{array}$ & $\begin{array}{c}\text { Males(\%) } \\
(\mathbf{N}=167)\end{array}$ & $\begin{array}{c}\text { Females }(\%) \\
(\mathbf{N}=153)\end{array}$ & $\chi^{2}$ \\
\hline Less than Rs.3000 (<75 US\$) & 43.72 & 44.44 & \multirow{5}{*}{0.16} \\
\hline $\begin{array}{c}\text { Rs. } 3001-6000(75.025-150 \\
\text { US\$) }\end{array}$ & 27.54 & 26.14 & \\
\hline $\begin{array}{c}\text { Rs. 6001-9000 ( } 150.025-225 \\
\text { US\$) }\end{array}$ & 14.37 & 15.04 & \\
\hline $\begin{array}{c}\text { Rs.9001-12000 ( } 225.025-300 \\
\text { US\$) }\end{array}$ & 8.38 & 7.84 & \\
\hline Above Rs. 12000 (>300 US\$) & 5.99 & 6.54 & \\
\hline
\end{tabular}

Among females, maximum percentage (44.44\%) had APCI less than or equal to Rs. 3000/-(75 US\$), 26.14\% had APCI was between Rs. 3001/- to Rs. 6000(75.025-150 US\$), $15.04 \%$ had APCI between Rs. 6001 to Rs.9000 (150.025225 US\$), 7.84\% had APCI between Rs. 9001 to Rs. 12000/(225.025-300 US\$-) and 6.54\% with APCI above Rs. 12000 (>300 US\$).

Table 4 presents the percentage distribution of subjects according to occupations. Among males, the highest percen- 
tage were taking to agriculture (32.94\%) as their occupation for their source of income followed by daily wage laborer $(20.36 \%), 17.96 \%$ were unemployed and $14.97 \%$ were in government service followed by $5.39 \%$ who were students, $4.79 \%$ who were running their own business and only $3.59 \%$ were army pensioners.

Table 4. Distribution of Subjects According to Occupations among Males and Females

\begin{tabular}{|c|c|c|c|}
\hline Occupations & $\begin{array}{c}\text { Males(\%) } \\
(\mathbf{N}=167)\end{array}$ & $\begin{array}{c}\text { Females }(\%) \\
(N=153)\end{array}$ & $\chi^{2}$ \\
\hline Student & 5.39 & 2.61 & \multirow{8}{*}{$94.29 * *$} \\
\hline Govt. Service & 14.97 & 10.46 & \\
\hline Daily wage labourer & 20.36 & 29.41 & \\
\hline Agriculture & 32.94 & 23.53 & \\
\hline Pension (Army) & 3.59 & 0 & \\
\hline Bussiness & 4.79 & 2.61 & \\
\hline Unemployed & 17.96 & 0 & \\
\hline Housewife & 0 & 31.38 & \\
\hline
\end{tabular}

Among females, maximum were housewives (31.38\%) followed by daily wage laborer $(29.41 \%)$. Females who were in the agricultural sectors were $25.53 \%$ and in government service were $10.46 \%$. Only very few i.e. $2.61 \%$ each were students and in business respectively.

Table 5 presents the percentage distribution of subjects according to marital status. Among males, the highest percentage of the subjects were married $(56.89 \%)$ followed by subjects who were unmarried $(28.75 \%)$ and widower $(7.18 \%)$. Very few males were either divorced or separated (3.59\% each).

Table 5. Distribution of Subjects According Marital Status among Males and Females

\begin{tabular}{|c|c|c|c|}
\hline Marital Status & $\begin{array}{c}\text { Males(\%) } \\
(\mathrm{N}=167)\end{array}$ & $\begin{array}{c}\text { Females(\%) } \\
(\mathbf{N}=153)\end{array}$ & $\chi^{2}$ \\
\hline Unmarried & 28.75 & 7.19 & \multirow{5}{*}{$35.06^{* *}$} \\
\hline Married & 56.89 & 62.74 & \\
\hline Widowed & 7.18 & 23.53 & \\
\hline Divorced & 3.59 & 3.95 & \\
\hline Separated & 3.59 & 2.59 & \\
\hline
\end{tabular}

Among females, 62.74\% were married followed by $23.53 \%$ who were widow. $7.19 \%$ females were unmarried and $3.95 \%$ were divorced. Only $2.59 \%$ females were separated.

Table 6 presents the percentage distribution of subjects according to age at marriage. Among males, the highest percentage $(37.0 \%)$ got married between the age of 20 24 years followed by $34.43 \%$ males who got married between the ages $25-29$ years, $17.65 \%$ between the ages $15-19$ years followed by $8.39 \%$ males who got married between the ages $30-34$ years. Only $2.53 \%$ males got married at the ages 35-39 years.

Table 6. Distribution of Subjects According to Age at Marriage among Males and Females

\begin{tabular}{|c|c|c|c|}
\hline Age at Marriage (years) & $\begin{array}{c}\text { Males(\%) } \\
(\mathrm{N}=167)\end{array}$ & $\begin{array}{c}\text { Females(\%) } \\
(\mathrm{N}=153)\end{array}$ & $\chi^{2}$ \\
\hline $15-19$ & 17.65 & 44.36 & \multirow{5}{*}{$29.27 * *$} \\
\hline $20-24$ & 37.0 & 35.21 & \\
\hline $25-29$ & 34.43 & 18.33 & \\
\hline $30-34$ & 8.39 & 1.4 & \\
\hline $35-39$ & 2.53 & 0.7 & \\
\hline
\end{tabular}

Among females, the highest number of subjects (44.36\%) got married between the ages 15-19years, followed by $35.21 \%$ who got married between the ages $20-24$ years and $18.33 \%$ who got married between the ages 25 -29years followed by $1.4 \%$ who got married between the ages 30 34 years. Only very few females $(0.7 \%)$ got married between the ages 35-39years.

Table 7 displays the percentage distribution of subjects according to BCG vaccination status. Among males, 31.74\% were vaccinated as against $68.26 \%$ who were not vaccinated. Among females, $32.68 \%$ were vaccinated whereas $67.32 \%$ were not vaccinated.

Table 7. Distribution of Subjects According to BCG Vaccination Status among Males and Females

\begin{tabular}{|c|c|c|c|}
\hline BCG vaccination status & $\begin{array}{c}\text { Males(\%) } \\
(\mathbf{N}=\mathbf{1 6 7})\end{array}$ & $\begin{array}{c}\text { Females(\%) } \\
(\mathbf{N}=\mathbf{1 5 3})\end{array}$ & \multirow{\chi}{*}{$\mathbf{2}$} \\
\hline \hline Vaccinated & 31.74 & 32.68 & \multirow{2}{*}{0.03} \\
\hline Not vaccinated & 68.26 & 67.32 & \\
\hline
\end{tabular}

BCG-Bacillus Calmette Guerin

\section{DISCUSSION}

A large number of tribals live on their own agricultural products, some collects forest products such as wild roots, fruits, honey, etc. The rest subsist on hunting food. The predominant factors for such variations may be hilly terrain, climatic differences, soil conditions and types of food available or otherwise. Some have religious taboos against several foods in different circumstances. The living conditions among most of these societies are not very healthy with many family members staying in small houses, sharing household area with domesticated animals.

In the present study the males were found to have better socio-economic status in terms of education level, access to safe drinking water and occupations. The availability of safe and adequate drinking water and sanitary measures has a direct bearing on the working conditions and health of the people and their capacity for optimum production. While access to safe drinking water and sanitation have been 
proven to be essential to good health and while the availability of water is a requisite for socio-economic development, there also exists a cause and effect relationship between water, health and development [25].

India is a land of villages and about 80 percent of its population lives in villages and surveys have shown that quite a large number of the population go to the open fields for defecation. This habit of defecation in the open fields is generations old and rooted firmly in the cultural behavior of the Indian village people [26]. In the present study, more than $70 \%$ of the males and females do not have proper toilets and defecate in the open fields. This type of living style is an open invitation to several contagious and infectious diseases, the most widely present tuberculosis being one of the several.

Among males there were more patients who were unmarried as compared to females. This could be because less number of unmarried females come to the TB centers because of the social stigma attached to TB. TB decreases the women's marriage prospects and increases the married women's vulnerability to divorce. Such stressors discourage women from acknowledging symptoms and appropriate care. In the present study maximum females married at a very young age as compared to their male counterparts.

The level of education which was highest among the males is indicative of the importance of education about one's health. A fact why lesser females come to the TB centers is because being a patriarchal society more importance is being given to the males than the females. If a male suffers from TB, wives are there to push them to get treatment but the opposite seldom happens. Tungdim et al. [12] found that the better the socio-economic status lesser is the chances of suffering from TB. But in the present study it was found that inspite of the lower socio-economic status there were fewer women who come to the TB centers to get treatment. The lesser number of female patients is a clear cut case of under reporting. Government, NGOs and social organizations should join hands to spread awareness for the success of the TB control programmes globally and specially in India. Notification rates of pulmonary TB for males are nearly always higher than for females $[6,27]$. The review of the various studies in the literature of health and social science research found that women progress from infection to active TB faster than men do, but the reported incidence of pulmonary TB among women is nearly always lower than for men [28]. Ahsan et al. [8] found that female patients were mostly illiterate and live in poor housing conditions.

The present finding points towards an important phenomenon of gender difference in the socio-cultural factors. Other studies found that there is gender differences in notification \& diagnosis due to social stigma attached to TB and that rates of compliance with treatment was found to be higher among female patients than males [7, 29-31]. In the present study it has been found that male patients were from families with better living conditions, were better educated as compared to their female counterparts showing that there is gender differences in reporting and diagnosis of TB. There is no significant difference in the income of males and females. This speaks for the fact that those who were aware and could afford, sent their female folks for diagnosis and treatment of tuberculosis. This was despite the fact that there is certainly a male preference in all the subjects, as evident from the literacy status that there were more males who were in the secondary and graduation levels of education as compared to females.

It is quite apparent that socio-economic and cultural factors though may not be the causative factors but are determinants for prevalence of gender differentials in tuberculosis. Social stigma is certainly a deterrent in TB treatment specially among female patients. Though there is a significant gender difference in the age at marriage, it is still unclear whether it is the age at marriage which predisposes them to TB. More work is needed on this aspect to reach to any explainable conclusion.

\section{CONCLUSION}

The lesser number of TB patients among females as compared to males reporting to the TB centers is clearly a case of gender difference in reporting and diagnosis of TB. The female subjects belonged to lower socio-economic status and were less educated. Both these factors i.e. poor living conditions combined with lesser awareness levels predisposes them to $\mathrm{TB}$ as well as binds them to social stigma.

\section{ACKNOWLEDGEMENTS}

The authors are thankful to the subjects who volunteered for the study. The authors are also grateful to (L) Dr. S.P. Khanna, the then Director, Delhi TB Centre for his cooperation and guidance before the start of the fieldwork. The authors also acknowledge their special thanks to Dr. Binod Kumar, the then State TB officer and all the Medical officers who have sincerely helped during the data collection. The financial assistance to Mary Grace Tungdim from Indian Council of Medical Research is highly acknowledged.

\section{REFERENCES}

[1] Raviglione MC, Snider DE, Kochi A. Global epidemiology of tuberculosis-mortality and morbidity of a worldwide epidemic. J Am Med Assoc 1995; 273(3): 220-26.

[2] Wise R. Global paradox. Lancet 1996; 348: 282

[3] Gupta S, Sood OP, Eds. Tuberculosis. Proceedings of the Seventh Round Table Conference, 2000, Delhi, Ranbaxy Science Foundation, Haryana, India.

[4] Singh MM. Tuberculosis: triumph and tragedy. Ind J Tuberc 2000; 47: 129-32.

[5] Diwan VK, Thomson Thomson A. Sex, gender and tuberculosis. Lancet 1999; 353(9157): 1000-1001.

[6] Thorson A, Diwan VK. Gender inequalities in tuberculosis; aspects of infection, notification rates, and compliance. Curr Opin Pulm Med 2001; 7(3): 165-69.

[7] Bashour H, Mamaree F. Gender differences and tuberculosis in the Syrian Arab Republic: patients' attitudes, compliance and outcomes. East Mediterr Health J 2003; 9(4): 757-68.

[8] Ahsan G, Ahmed J, Singhasivanon P, et al. Gender difference in treatment seeking behaviors of tuberculosis cases in rural communities of Bangladesh. Southeast Asian J Trop Med Public Health 2004; 35(1): 126-35.

[9] Marmot MG, McDowell ME. Mortality decline and widening social inequalities. Lancet 1996; ii: 274-6.

[10] Marmot MG, Shipley MJ. Do socioeconomic differences in mortality persist after retirement? 25 year follow up of civil 
servants from the first Whitehall study. Br Med J 1996; 313: 11771180 .

[11] Marmot M, Feeney A. General explanations for social inequalities in health. IARC Science Publication 1997; 138: 207-28.

[12] Tungdim MG, Kapoor S, Kapoor AK. Tribes, tuberculosis and treatment: A study in Northeast India. In: Pathak RK, Sinha AK, Banerjee BG, Vasishat RN, Edwin CJ, Eds. Bio-social issues in Health. Northern book center, Delhi 2008; pp. 520-28.

[13] Census of India. Series 20, Provisional Population Totals, paper 1, 1991; p. 22.

[14] Hungyo P. The chieftainship and the maintenance of customary law among the Tangkhul Nagas. Seminar on Customary Law, Calcutta, 1978.

[15] Gangte TS. Search for new identity among the tribals of Manipur. Man Life 1984; vol. 10(3 \& 4).

[16] Lal Dena. Social and Political Institutions of the Hmars, MS, 1977.

[17] Pudaite R. The Education of the Hmar People. Sielmat, Manipur, 1963.

[18] Tungdim MG. A study on the social organization and the finger ball patterns of the Kabuis of Namthanlong village. B.Sc. [dissertation]. Imphal, Manipur University 1993.

[19] Mackenzie A. North East Frontier of Bengal. Calcutta, Home Department Press 1884.

[20] Stewart R. "Notes on Northern Cachar". J Asiat Soc Bengal 1855; 24: 625-33.
[21] Shaw W. Notes on Thadou Kukis. Assam Government Publication, Shillong 1929.

[22] Hutton JH. "Introduction". In: Shaw W, Ed. Notes on Thadou Kukis, Assam Government Publication, Shillong 1929.

[23] Gin ZTJ. History of the Zomi family. Tedim, Burma 1973.

[24] Gougin T. Personal Communication, Churachandpur, Manipur, 2000.

[25] Shukla SR. national water supply and sanitation program. National Health Program(Series 8), National Institute of Health and Family Welfare, Delhi 1988.

[26] Park JE, Park K. Park's textbook of preventive medicine, Banarsidas Bhanot Publishers, Jabalpur 1995.

[27] Bordorff MW, Nagelkerke NJD, Dye C, et al. Gender and tuberculosis: a comparison of prevalence surveys with notification data to explore sex differences in case detection. Int J Tuberc Lung Dis $2000 ; 4(2)$ : 123-32.

[28] WHO. Gender in tuberculosis research. Gender and health research series 2004.

[29] Murray CJL, Lopez AD, Eds. The global burden of disease and risk factors in 1990. Geneva, World Health Organization 1996.

[30] Hudelson P. Gender differentials in tuberculosis: the role of socioeconomic and cultural factors. Tubercle Lung Dis 1996; 77: 391400.

[31] Long $\mathrm{NH}$, Johansson E, Lonnroth $\mathrm{K}$, et al. Longer delays in tuberculosis diagnosis among women in Vietnam. Int $\mathrm{J}$ Tuberc Lung Dis 1999; 3(5): 388-93. 